Int. J. Dev. Biol. 53: 615-622 (2009)

doi: $10.1387 / \mathrm{ijdb} .092850 \mathrm{mh}$

\title{
A novel in vitro system for studying cardiomyocyte differentiation with medaka embryonic cells
}

\author{
MASAO HYODO* ${ }^{* 1}$, SHINJI MAKINO ${ }^{2}$, YASUNORI AWAJI ${ }^{1}$, YOHEI SAKURADA ${ }^{1}$, TOMOICHI OHKUBO ${ }^{3}$, \\ MITSUSHIGE MURATA ${ }^{2}$, KEIICHI FUKUDA ${ }^{2}$ and MICHIO TSUDA ${ }^{4}$

\begin{abstract}
${ }^{1}$ Department of Biological Science and Technology, Tokai University, Numazu, Japan, ${ }^{2}$ Department of Regenerative Medicine and Advanced Cardiac Therapeutics, Keio University School of Medicine, Shinjuku, Tokyo, Japan, ${ }^{3}$ Teaching and Research Support Center, and ${ }^{4}$ Department of Molecular Life Science, Tokai University School of Medicine, Boseidai, Isehara, Japan
\end{abstract}

\begin{abstract}
Our studies revealed that dissociated cells from medaka (the fresh-water fish, Oryzias latipes) blastula-stage embryos differentiate into many rhythmically contracting cells when incubated with a conditioned medium from a cell line. Analyses of these cells by immunostaining, electron microscopy, expression of marker genes, action potential recordings and pharmacological responses all showed the characteristics of myocardial cells. We succeeded in purifying the cardiac cell-inducing factor from the conditioned medium by 523,100 -fold with $8 \%$ recovery of the protein. Analysis of its amino-acid sequence by mass spectrometry revealed the factor to be medaka activin $A_{2}$ (homodimer of inhibin $\beta A_{2}$ subunit). Recombinant human activin $A$ showed the same cardiac cell-inducing activity toward medaka embryonic cells. Our results demonstrate that activin $A$ is a potent factor for medaka myocardial cell differentiation. This culture method should provide a novel and simple experimental system to study cardiomyocyte differentiation in vitro.
\end{abstract}

KEY WORDS: medaka, activin, cardiomyocyte, embryonic cell culture

\section{Introduction}

Pluripotent embryonic stem (ES) cell lines have been established from the inner cell masses of early human (Thomson et al., 1998) or other mammalian embryos and are expected to provide a unique system for tissue engineering. The technology to induce pluripotent stem cells (the iPS cells) from cultured mouse (Takahashi and Yamanaka, 2006) or human (Takahashi et al., 2007) somatic cells has recently been developed. Thus it will be possible to create pluripotent cells directly from somatic cells of patients. Differentiation of ES or iPS cells into cardiomyocytes has been demonstrated (Kehat et al., 2001; Xu et al., 2002; Passier et al., 2005; Denning et al., 2006; Laflamme et al., 2007; Takahashi et al., 2007). Attempts to treat heart disease using these cells have been carried out and transplantation of human ES cell-derived cardiomyocytes to infarcted hearts of athymic rat or mouse was shown to improve heart function (Laflamme et al., 2007; van Laakea et al., 2007). While these methods are expected to be used in regenerative cell therapy for treatment of human heart disease, more detailed studies are required for a better understanding of the molecular mechanisms of early cardiac differentiation, proliferation and maturation of the induced cardiomyocytes.

The protocol for in vitro induction of the cardiomyocytes was based on the results of experiments using animal models such as amphibians and chicken. Experiments with tissue fragments from embryos of these animals revealed that cardiac myogenesis is regulated by several temporally and spatially distinct signaling events. Although participation of many protein factors has been reported in cardiogenesis including activin, bone morphogenetic proteins (BMPs), or fibroblast growth factors (FGFs) (Lough and Sugi, 2000; Yutzey and Kirby, 2002; Zaffran and Frasch, 2002; Brand, 2003; Fukuda and Yuasa, 2006), the primary mechanisms underlying cardiac induction, especially which signal initiates specification, have yet to be fully characterized. In chicken embryos, there seem to be distinct mechanisms between the cardiac cell-inducing activities of early stage hypoblasts and those of late stage antero-lateral $(\mathrm{AL})$ endo-

Abbreviations used in this paper: AL-antero-lateral; BMP, bone morphogenetic protein; CM, conditioned medium; ES, embryonic stem.

\footnotetext{
*Address correspondence to: Masao Hyodo. Department of Biological Science and Technology, Tokai University, Numazu, 410-0395, Japan.

Fax: +81-55-968-1156. e-mail address: hyodo@tokai.ac.jp
}

Supplementary Material for this paper (a movie) is available at: http://dx.doi.org/10.1387/ijdb.092850mh

Accepted: 1 December 2008. Published online: 23 January 2009. Edited by: Makoto Asashima.

ISSN: Online 1696-3547, Print 0214-6282

() 2009 UBC Press

Printed in Spain 
derm where hypoblast-derived signals (activin) act upstream of the heart-inducing signals provided by $\mathrm{AL}$ endoderm (BMPs and FGFs) (Sugi and Lough, 1995; Schultheiss et al., 1995; Lough et al., 1996; Yatskievych et al., 1997; Ladd et al., 1998; Barron et al., 2000). In frog embryos, induced differentiation of animal cap cells into cardiomyocytes in vitro was shown after treatment with activin (Ariizumi et al., 1996; Ariizumi et al., 2003).

Small fresh-water fish such as medaka (Oryzias latipes) and zebrafish (Danio rerio) are attracting increasing interest as animal models for research in vertebrate development. We have been using pluripotent cells isolated from early stage medaka embryos for cell culture experiments (Hyodo et al., 1998). Medaka produces considerable numbers of eggs daily under conditions of controlled water temperature and light periods. The eggs are relatively large (about $1 \mathrm{~mm}$ in diameter) and transparent so that they can be easily observed or manipulated under low magnification microscopy. The recent release of a draft genome sequence for medaka should facilitate research in many fields (Kasahara et al., 2007). Although attempts to establish ES cells from fish embryos have been reported (Hong et al., 1998; Fan and Collodi, 2006), success remains limited. Furthermore, there have been no reports of studies employing in vitro fish cell culture to investigate the induction of cardiomyocytes. During our study to culture medaka embryonic cells, we found that a conditioned medium prepared with a medaka cell line effectively induces cardiogenesis in vitro. We report here the purification and identification of the protein factor responsible for this induction. The factor was found to be medaka activin $A_{2}$. Human activin $A$ was also shown to have cardiac cell-inducing activity in this new experimental system.

\section{Results}

\section{Induction of rhythmically contracting cells from medaka embryonic cells}

While we were attempting to establish ES cells from medaka

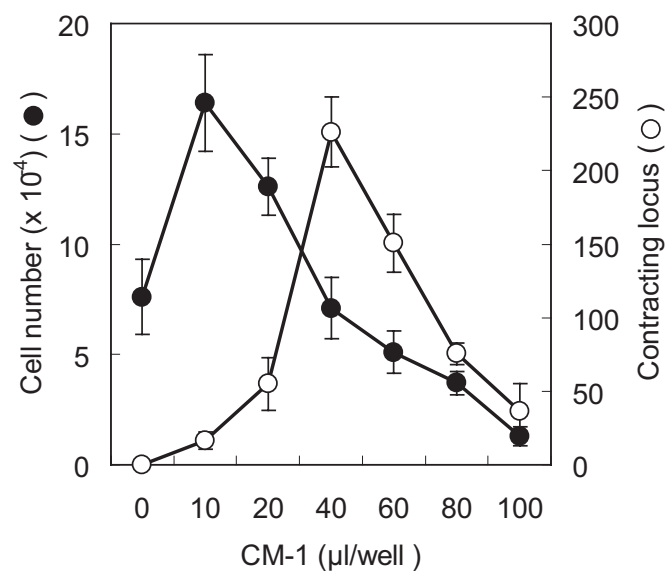

Fig. 1. Dose-dependent effects of the conditioned medium (CM-1) on the cell growth and cardiac differentiation of medaka embryonic cells. Closed circles: number of cells/well. Open circles: number of contracting loci/well. Values represent mean $\pm S E(n=5$-7).
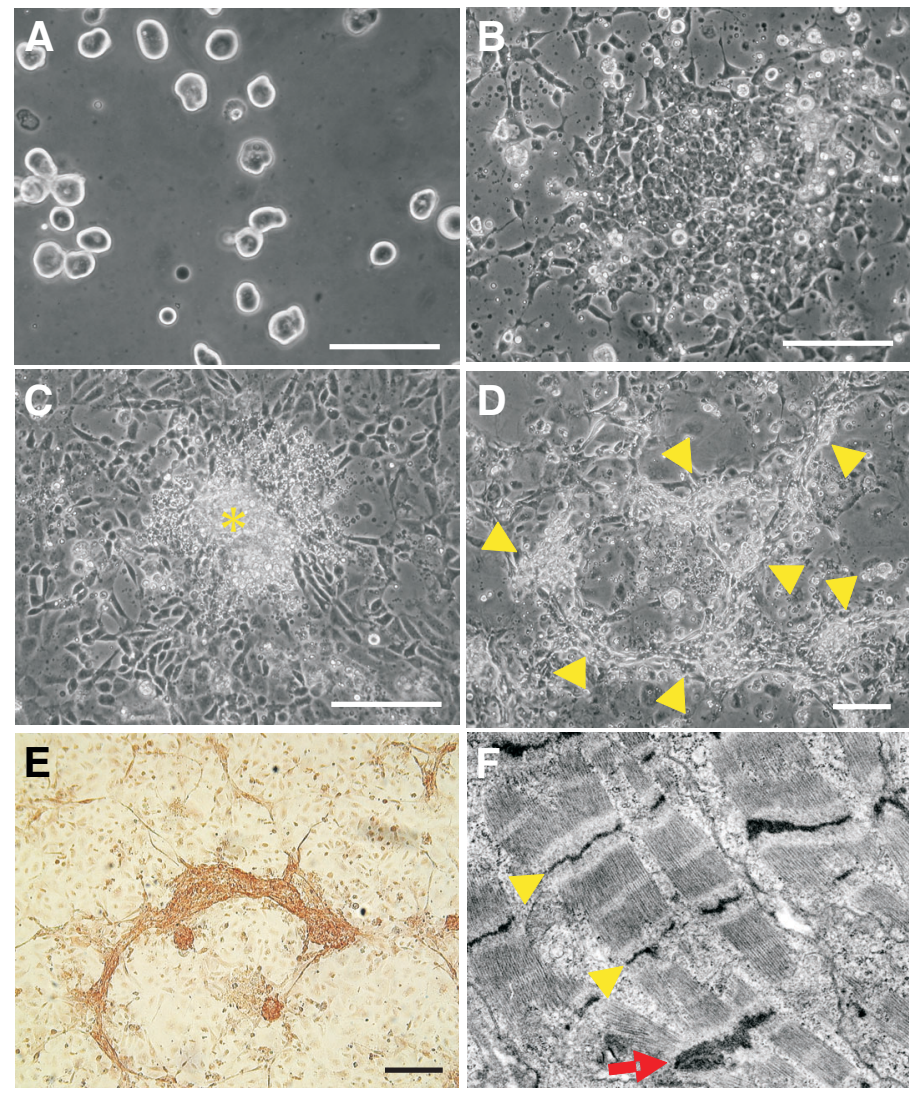

Fig. 2. Differentiation of cardiomyocytes from medaka embryonic cells dissociated at the blastula stage. (A-E) Light microscopic observation. (A) Cells dissociated from blastula-stage embryos. (B) Cells incubated for 1 day. (C) Cells incubated for 2 days. An asterisk indicates apoptotic cells. (D) Cells incubated for 6 days. Arrowheads indicate contracting loci. (E) Immuno-histochemical micrograph of cells incubated for 5 days. Scale bar in (A-E), $100 \mu \mathrm{m}$. (F) Transmission electron micrograph of sectioned beating cells after 14 days of incubation. Arrowheads indicate Z-band and an arrow indicates an intercalated disc.

embryos (Hyodo et al., 1998), we tested the effect of the conditioned medium. The conditioned media were prepared from 6 medaka fibroblast cell lines established independently in our laboratory. They were added to cultures of dissociated cells prepared from the blastula-stage medaka embryos. Then we found that one of them (CM-1) induced spontaneously contracting cells after several days of incubation. Differentiation occurred in primary cultures in which most of the cells were growing as a monolayer.

At first, we examined the dose-dependent effects of CM-1 and the results are shown in Fig. 1. For determination of cardiac cell-inducing activity, the contracting loci (groups of cardiomyocytes) were counted under a microscope after 5 days of incubation. The results show that the differentiation of contracting cells was dependent on $\mathrm{CM}-1$. Without the addition of $\mathrm{CM}-1$, contracting cells were almost never observed. When $10-20 \mu \mathrm{l}$ of CM-1 was added to the culture, cell growth was promoted and lower level of cardiac differentiation was observed. Then a maximum number of contracting locus was found when $40 \mu \mathrm{l}$ of $\mathrm{CM}-1$ was added to a $1.2 \mathrm{ml}$ culture. Under the same conditions, 
cell number decreased to about $50 \%$ of the maximum. When increasing the amount of $\mathrm{CM}-1$ to more than $40 \mu \mathrm{l} /$ well, extensive cell death occurred so that both the cell number and yield of contracting loci decreased. These results show that differentiation occurred within a narrow concentration range of a factor contained in CM-1.

\section{Characterization of rhythmically contracting cells}

Fig. 2 shows a typical result of microscopic observation of cultured medaka embryonic cells. At first, blastoderms were excised from blastula-stage embryos, and blastomeres were dissociated into single cells (Fig. 2A). Cells were then incubated in $1.2 \mathrm{ml}$ of 199ES2 medium containing $40 \mu \mathrm{l} \mathrm{CM}-1$, the most suitable conditions for differentiation of the contracting cells. After 1 day of incubation, many colonies of epithelial cells were observed (Fig. 2B). The cells were small and each cell contained a large nucleus and a small amount of cytoplasm. At the center of colonies, cells were tightly associated with each other so that the cell boundaries were not clear. Their appearance was similar to those of mammalian ES cells. After incubation for 2 days, some cells at the center of these colonies died and degraded (Fig. 2C). Many of the surviving cells were found to differentiate into rhythmically contracting cells. The cells started beating after incubation for 2-3 days. This beating was weak and irregular at first, but it became regular and strong after 4 days of incubation. In intact embryos, heart contractions started at approximately the same time (Iwamatsu, 2004) as those in the in vitro culture system. Fig. 2D shows groups of contracting loci incubated for 6 days. Contracting cells are also shown in the online data supplements (Movie 1). The pulse rate was approximately $100-110 / \mathrm{min}$ at $28^{\circ} \mathrm{C}$, and this was similar to those of intact embryonic heart. Such rhythmical contractions continued for more than 2 months with weekly medium changes.

To characterize these rhythmically contracting cells, the expression of a cardiac troponin I in cultured cells was investi-

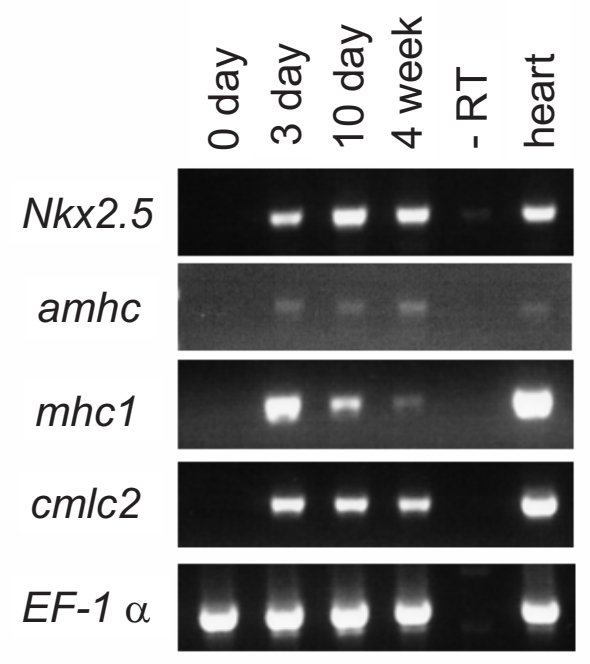

Fig. 3. The expression of 5 genes (Nkx2.5, amhc, mhc1, cmlc2 and EF$1 \alpha)$ was analyzed by RT-PCR. RNA was extracted from cells immediately after dissociation of the blastoderm (0 day), after incubation of up to 4 weeks, or from the intact medaka heart. In negative control reactions, reverse transcriptase was omitted (-RT).

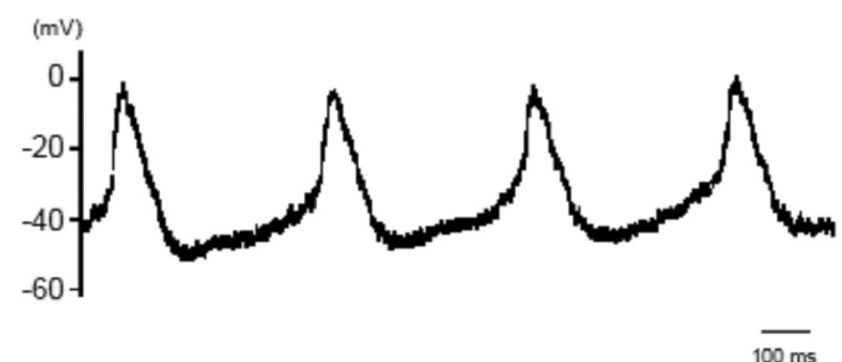

Fig. 4. Electrophysiological analysis of cardiomyocytes differentiated in vitro.

gated by immuno-staining with a monoclonal antibody. As shown in Fig. 2E, the contracting loci were positively stained with the anti-cardiac troponin I antibody. Among cells incubated without $\mathrm{CM}-1$, no contracting cells formed and cells were not stained with the monoclonal antibody (data not shown). Fig. $2 F$ shows a result of ultrastructural analysis of embryonic cellderived beating cells incubated for 14 days. The electron micrograph shows sarcomeric organization with Z-bands and intercalated discs. Thus, the results of immunohistochemical and ultrastructural analyses indicated that the spontaneously contracting cells displayed characteristics of cardiomyocytes.

Fig. 3 shows the results of gene expression analysis by RTPCR. The expression levels of four cardiac-specific genes, including $N k x 2.5$ (cardiac specific homeobox gene), amhc (atrium myosin heavy chain), mhc1 (myosin heavy chain 1), $\mathrm{cm} / \mathrm{c} 2$ (cardiac myosin light chain 2), as well as EF-1 $\alpha$ (elongation factor $1 \alpha$ ) as a control, were examined. The results show that expression of the cardiac specific genes can be detected after incubation in $\mathrm{CM}-1$ for 3 days and continues for at least 4 weeks.

An electrophysiological study was carried out on the contracting cells after 2 weeks of incubation in CM-1 (Fig. 4). A cardiomyocyte-like action potential was recorded from these spontaneously beating cells and shows the following properties: (1) a relatively long action potential duration or plateau; (2) a relatively shallow resting membrane potential; and (3) a pacemaker-like late diastolic slow depolarization. They revealed a sinus node-like action potential rather than action potentials like those of matured ventricular cardiomyocytes. These results confirmed that the contracting cells were cardiomyocytes.

\section{Pharmacological responses of the contracting cells}

To further characterize the properties of differentiated cardiomyocytes derived from medaka embryonic cells, their pharmacological responses were examined. For this purpose, cardiomyocytes were incubated with various concentrations of drugs and their beating frequencies were measured. The contracting cells were treated with phenylephrine (an $\alpha_{1}$ - adrenergic receptor agonist; Fig. 5A), or isoproterenol (a $\beta_{1}$-adrenergic receptor agonist; Fig. $5 \mathrm{~B})$. Both of these drugs enhanced contraction rate in a dose-dependent manner. Clenbuterol (a $\beta_{2}$-adrenergic receptor agonist; Fig. $5 \mathrm{C}$ ) caused slight increases in the beating rate. Fig. 5D shows that the beating frequency was decreased by diltiazem (a calcium channel blocker) in a concentration-dependent manner and that treatment of cells 

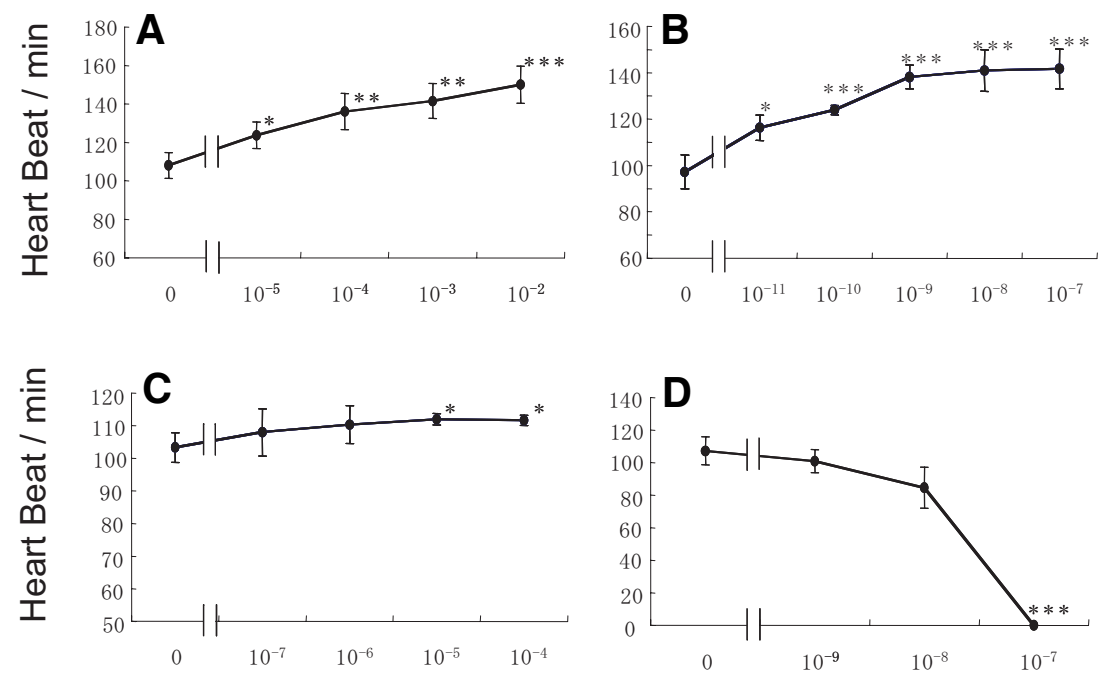

Concentration (M)

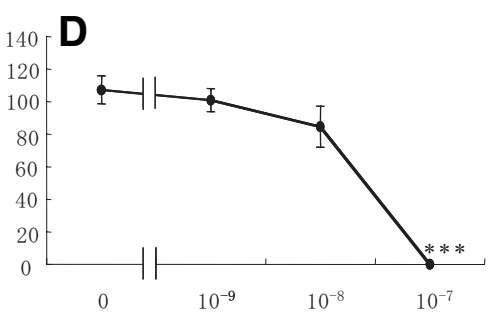

Concentration (M)

Fig. 5. Study of pharmacological responses with differentiated cardiomyocytes. Effect of phenylephrine ( $\alpha_{1}$-adrenoceptor agonist) (A), isoproterenol ( $\beta_{1}$-adrenoceptor agonist) (B), clenbuterol ( $\beta_{2}$-adrenoceptor agonist) (C) and diltiazem (calcium channel blocker) (D) on medaka cardiomyocytes induced from embryonic cells. Values represent mean \pm SE $(\mathrm{n}=3-4) .{ }^{*} p<0.05, * * p<0.005, * * * p<0.001$

with $10^{-7} \mathrm{M}$ diltiazem stopped contractions completely. These results show that differentiated cardiomyocytes responded to adrenergic agonists and $\mathrm{Ca}^{2+}$ blockers similarly to those in vivo.

\section{Purification and identification of the cardiac cell-inducing factor}

To purify the cardiac cell-inducing factor from the conditioned medium, fractionation steps employing ammonium sulfate, SPSephadex, Sephadex G-75, hydroxyapatite and SP-Sepharose columns were performed. For determination of cardiac cellinducing activity during these steps, one unit was defined as the amount of activity that induces one contracting locus in a well. Using these procedures, the cardiac cellinducing factor was purified by 523,100 -fold with $8 \%$ protein recovery from $\mathrm{CM}-1$ (Table 1). The molecular mass of the factor was estimated to be 24-28 kDa by Sephadex G-75 column chromatography (data not shown). Fig. 6 shows a final result of SP-sepharose column chromatography. The activity was detected as a discrete peak at approximately $40 \mathrm{mmol} / \mathrm{L} \mathrm{NaCl}$.

For determination of the amino-acid sequence of this factor, the purified protein was digested by trypsin and separated peptides were analyzed by a mass spectrometer (Ultraflex MALDI LIFT TOF/TOF MS, Brukar Daltonics K. K.). Peptide mass fingerprint (PMF) data identified the factor as inhibin $\beta \mathrm{A}_{2}$ subunit (EMBL/GenBank/DDJB accession no. AB009408) (Tada et al., 1998). Inhibin is composed of two peptides, $\alpha$ and $\beta$ subunits, and activin is a homodimer of inhibin $\beta$ subunits. Since only the inhibin $\beta A_{2}$ subunit was detected, we conclude that the purified cardiac cell-inducing factor is the medaka activin $A_{2}\left(\beta A_{2}\right.$ homodimer). Fig. 7A shows the dose-dependent ef- fects of the purified medaka activin A2 on the dissociated embryonic cells. The results are similar to those with $\mathrm{CM}-1$ (Fig. 1).

\section{Human activin A can induce medaka cardiac myocytes}

We next examined whether human activin $A$ (78\% identity to medaka activin $A_{2}$ in amino-acid sequence) possesses the same cardiac cell-inducing activity towards medaka embryonic cells. The results are shown in Fig. $7 \mathrm{~B}$ and indicate that recombinant human activin $A$ has the same activity as medaka activin $A_{2}$. It promoted cell growth at low concentrations, induced myocardial cell differentiation at medium-range concentrations and caused cell death at higher concentrations. The results in Fig. 7 show that $1 \mathrm{ng} /$ well $(0.83 \mathrm{ng} / \mathrm{ml})$ of the medaka activin $A_{2}$ can induce $\sim 300$ contracting loci, whereas $3 \mathrm{ng} /$ well $(2.5 \mathrm{ng} / \mathrm{ml})$ of human activin A can induce 200 contracting loci. Microscopic observations of cultured cells incubated with human activin A showed them to have morphological appearances indistinguishable from those of cells induced with CM-1 or purified medaka activin $A_{2}$.

Then we performed molecular identification of the cardiomyocytes induced by human activin $\mathrm{A}$. The rhythmically contracting cells were positively stained with the anti-cardiac troponin I antibody (Fig. 8). And RT-PCR experiments revealed that expression of the cardiac specific genes can also be detected (Fig. 9). These results confirm that activin $A$ is a potent inducer of myocardial cells from medaka embryonic cells.

\section{Discussion}

\section{Differentiation of cardiomyocytes in vitro}

We found that when dissociated cells isolated from the medaka blastula-stage embryos were incubated with the conditioned

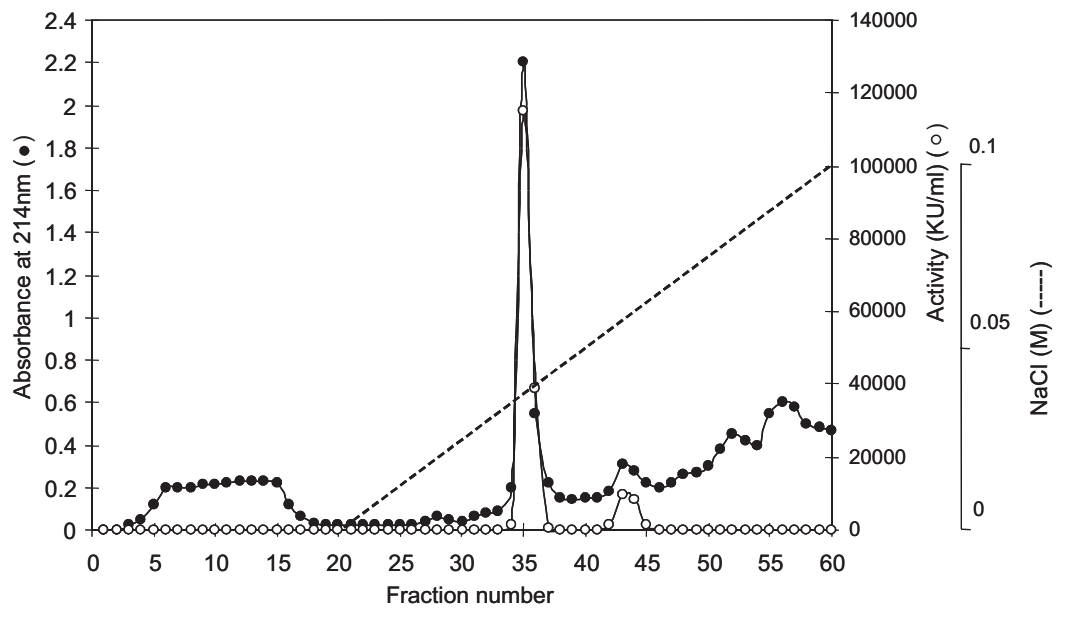

Fig. 6. A profile of the SP-Sepharose column chromatography. Proteins were eluted with a linear gradient of $0-100 \mathrm{mmol} / \mathrm{L} \mathrm{NaCl}$ in basal buffer at a flow rate of 0.5 $\mathrm{ml} / \mathrm{min}$. Activity was detected as a discrete peak at 40-50 mmol/L NaCl. Open circles: activity of cardiac cell-inducing factor (kilo units/ml). Closed circles: absorbance at 214 $\mathrm{nm}$. Dashed line: $\mathrm{NaCl}$ concentration. 


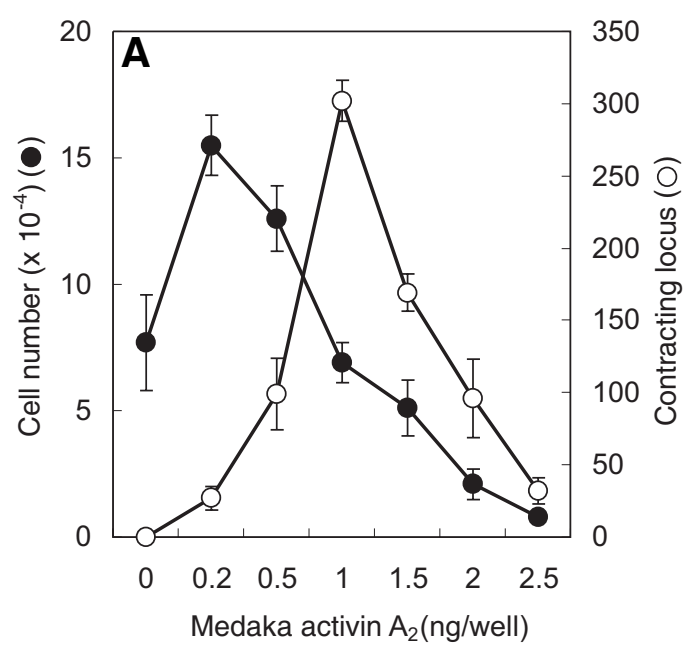

medium (CM-1), many cells differentiated into rhythmically contracting cells. These cells were characterized as cardiomyocytes. Development of heart has been shown in in vitro cultures of avian (Sugi and Lough, 1995; Schultheiss et al., 1995; Lough et al., 1996; Yatskievych et al., 1997; Ladd et al., 1998; Lough and Sugi, 2000; Barron et al., 2000; Yutzey and Kirby, 2002) and amphibian (Ariizumi et al., 2003) embryo explants. In most of these cases, the cells develops into complex structures containing different tissue lineages. In contrast to these results, our study showed that dissociated medaka blastomeres incubated with $\mathrm{CM}-1$ formed monolayer colonies and differentiated into spontaneously contracting cells (Fig. 2). This induction of cardiac differentiation is highly reproducible and the ratio of cardiomyocytes is about 30 $40 \%$ of the surviving cells as judged by microscopic observation of the intact and immuno-stained cells. Differentiation of myocardial cells was the most significant event in this culture system. The rest of the culture was composed of epithelial or spindle-shaped cells. In some cases, a small number of notochord cells (less than $5 \%$ of survived cells) which were composed of typical vacuolized cells, were formed. However, these appeared without $\mathrm{CM}-1$, and addition of $\mathrm{CM}-1$ decreased their number, so that differentiation of notochord occurred spontaneously and was not dependent on the factor in the conditioned medium.

\section{Identification of the factor as activin $A_{2}$}

Through successive protein fractionation steps beginning with a large quantity of the conditioned medium, we succeeded in purifying the cardiomyocyte-inducing factor as a single peak. Analysis of the amino-acid sequences of trypsinized peptide fragments using a mass spectrometer revealed that the factor was medaka activin $A_{2}$.

When the purified protein fraction was added to cultured medaka embryonic cells, it showed the same dose-dependent effects on cell growth and differentiation as the conditioned medium (Fig. 7A), and differentiated cell morphologies were indistinguishable from those formed with $\mathrm{CM}-1$. Thus, the effect of myocardial cell differentiation induced by $\mathrm{CM}-1$ was attributed solely to activin $A_{2}$. In addition, experiments with human activin A confirmed an effect of activin on the differentiation of cardiomyocytes (Figs. 7B, 8, 9).

\section{Differentiation of cardiomyocytes by activin $A_{2}$}

The roles of activins in mesoderm induction and axis formation during the early stages of development have been studied in amphibian embryos (Asashima, 1994; Ariizumi and Asashima, 2001; Sedohara et al., 2006). Activin was found to induce a broader range of tissues, from ventral to dorsal types, in a gradient fashion depending on its concentration. For example, in the animal cap assay using Xenopus embryos, activin induced ventral types of mesoderm tissue at a low concentration, muscle and neural tube at a middle range of concentration, and dorsal mesoderm, such as notochord, at a high concentration (Asashima, 1994). Activin A was also shown to induce heart tissues in Xenopus (Ariizumi et al., 2003) and newt (Cynops pyrrhogaster) (Asashima et al., 2000) animal caps at a high concentration (10$1,000 \mathrm{ng} / \mathrm{ml}$ ). In our study, it was interesting that differentiation of cardiomyocytes occurred at much lower concentrations of activin $A_{2}$ compared with those reported with amphibian embryos. In our study, the most efficient amount for the differentiation of cardiomyocytes was at $0.83 \mathrm{ng} / \mathrm{ml}$ of medaka activin $A_{2}$ or $2.5 \mathrm{ng} / \mathrm{ml}$ of human activin $\mathrm{A}$.

The involvement of activins in mesoderm induction in medaka embryos was shown by Wittbrodt and Rosa (1994). They demonstrated that only maternally provided activin protein is required for the formation of mesoderm and body axis by inhibiting the

TABLE 1

\section{PURIFICATION OF THE CARDIAC CELL INDUCING FACTOR FROM CONDITIONED MEDIUM}

\begin{tabular}{lccccc} 
Steps & $\begin{array}{c}\text { Total } \\
\text { K Units }\end{array}$ & $\begin{array}{c}\text { Recovery } \\
(\%)\end{array}$ & $\begin{array}{c}\text { Total } \\
\text { Protein }(\mathbf{m g})\end{array}$ & $\begin{array}{c}\text { Specific } \\
\text { Activity }\end{array}$ & $\begin{array}{c}\text { Purification } \\
\text { (fold) }\end{array}$ \\
\hline Medium & 38,500 & 100 & 72,000 & 0.535 & 1 \\
$\left(\mathrm{NH}_{4}\right)_{2} \mathrm{SO}_{4}$ & 23,940 & 62.2 & 6,600 & 3.63 & 6.79 \\
1st SP-column & 22,640 & 58.8 & 139 & 162.9 & 304 \\
Sephadex G-75 & 14,151 & 36.8 & 1.82 & 7,775 & 14,533 \\
HA-column & 7,640 & 19.8 & 0.41 & 18,634 & 34,830 \\
2nd SP-column & 3,080 & 8.0 & 0.011 & 279,859 & 523,101 \\
\hline
\end{tabular}



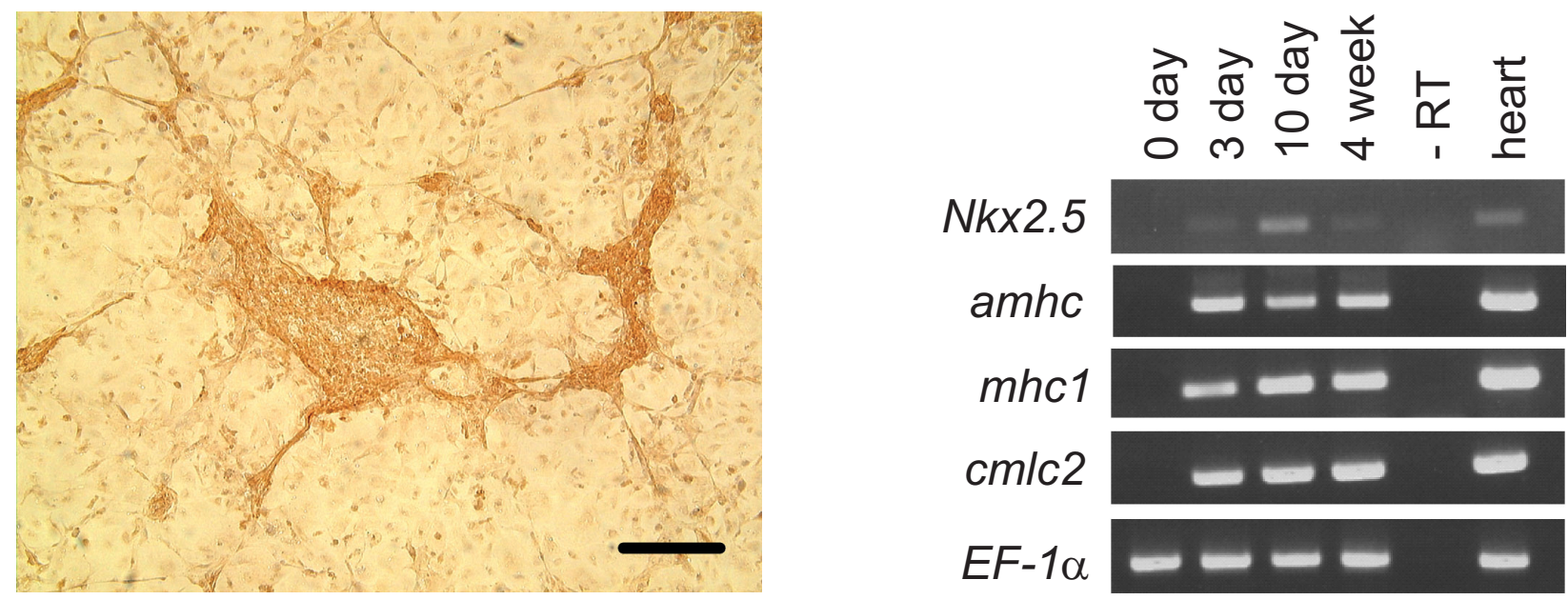

Fig. 8 (Left). Immuno-histochemical micrograph of cells incubated with human activin A for $\mathbf{5}$ days. $B a r, 100 \mu m$.

Fig. 9 (Right). The expression of 5 genes ( $N k x 2.5$, amhc, mhc1, cmlc2 and EF-1 $\alpha$ ) in the cells incubated with human activin A was analyzed by RT-PCR. RNA was extracted from cells immediately after dissociation of the blastoderm (0 day), after incubation of up to 4 weeks, or from the intact medaka heart. In negative control reactions, reverse transcriptase was omitted (-RT).

expression of zygotically transcribed activins. They also described a temporal difference in the zygotic expression of medaka activins. Activin $B$ mRNA first appears in the late blastula, while transcripts of activin $A_{1}$ and $A_{2}$ were detected in the late gastrula. In this study, we showed that activin $A_{2}$ induces cardiomyocytes in cultured medaka embryonic cells at high frequency. We consider from our results that activin $\mathrm{A}_{2}$ may have a specific role in the induction of heart in vivo. The temporal difference in the expression of activins (Wittbrodt and Rosa, 1994) may be related to functional differences in development. The possibility of a direct function of medaka activin $\mathrm{A}_{2}$ in the differentiation of cardiomyocytes in vivo needs to be clarified by further investigation.

\section{Materials and Methods}

\section{Cell culture}

From the blastula-stage (stage 10-11) (Iwamatsu, 2004) medaka embryos, blastoderms were excised and were dissociated to single cells (Hyodo et al., 1998). The 199ES2 medium was used for cell culture which contained 199 medium (Nissui Seiyaku Co.) supplemented with $20 \mathrm{mmol} /$ L HEPES ( $\mathrm{pH} 7.5$ ), $50 \mathrm{nmol} / \mathrm{L}$ 2-mercaptoethanol, $1 \mathrm{mmol} / \mathrm{L}$ sodium pyruvate and $15 \%$ fetal calf serum (Hyclone Co.). The cell suspension was transferred to $0.1 \%$ gelatin-coated 24-well plates (Nalge Nunc Int.). Cells from 20 embryos were incubated in a well with $1.2 \mathrm{ml}$ of $199 \mathrm{ES} 2$ medium containing a conditioned medium or a fractionated protein. The plates were incubated at $28^{\circ} \mathrm{C}$.

To assay their activity during protein fractionation steps, one unit was defined as the amount of activity that induces one contracting locus in a well. Recombinant human activin A (R\&D Systems, Inc.) was prepared as a $10 \mu \mathrm{g} / \mathrm{ml}$ stock solution according to recommendation of the supplier.

\section{Conditioned medium}

A medaka cell line (MR1) (Hyodo et al., 1998) was used as feeder cell for the conditioned medium (CM-1). This fibroblastic cell line was derived from 5-day-old medaka embryos and was serially transferred in every 7 10 days for more than 5 years. To prepare CM-1, approximately $1 \times 10^{6}$ cells were incubated with $5 \mathrm{ml}$ of the culture medium in a culture flask $\left(25 \mathrm{~cm}^{2}\right.$, Nalge Nunc Int.). After incubation at $28^{\circ} \mathrm{C}$ for 5 days, the culture medium was collected and passed through a $0.2 \mu \mathrm{m}$ membrane filter. $A$ large scale culture was carried out in a $185 \mathrm{~cm}^{2}$ culture flask (Nalge Nunc Int.) with $60 \mathrm{ml}$ of culture medium.

\section{Immunostaining}

For immuno-histochemical study, cells dissociated from 50-60 embryos were cultured in a glass chamber slide (Nalge Nunc Int.) with $2.2 \mathrm{ml}$ of 199ES2 medium containing $80 \mu \mathrm{l}$ of CM-1. After 5 days of incubation, cells were fixed in $4 \%$ paraformaldehyde in phosphate-buffered saline (PBS) for $30 \mathrm{~min}$ at room temperature and rinsed with PBS. The cells were permeabilized by freezing and thawing, and incubated overnight at $4^{\circ} \mathrm{C}$ with an anti-troponin I antibody (monoclonal mouse anti-troponin I, bovine cardiac muscle, Advanced ImmunoChem. Inc.) at a dilution of 1:1,000. The secondary antibody was peroxidase-linked sheep anti-mouse IgG (Amersham Biosci. Co.) at a dilution of 1:100. The cells were stained in diamiobenzidine (DAB) solution ( $50 \mathrm{mM}$ Tris- $\mathrm{HCl}, \mathrm{pH} 7.6,0.2 \mathrm{mg} / \mathrm{ml} \mathrm{DAB}$, $0.65 \mathrm{mg} / \mathrm{ml} \mathrm{NaN}_{3}$, and $0.5 \% \mathrm{H}_{2} \mathrm{O}_{2}$ ) for $3-5 \mathrm{~min}$ at room temperature and then in a hematoxylin solution for $10 \mathrm{sec}$.

\section{Electron microscope}

For transmission electron microscopy, cells were fixed in $2.5 \%$ glutaraldehyde in $50 \mathrm{mmol} / \mathrm{L}$ phosphate buffer $\left(\mathrm{pH} \mathrm{7.4)}\right.$ at $4^{\circ} \mathrm{C}$ for $1 \mathrm{~h}$, postfixed in $1 \%$ OsO4 in the same buffer for $1 \mathrm{~h}$, dehydrated in a graded ethanol series, and embedded in Quetol-812. Thin sections were used for staining with uranylacetate and lead solution, and then observed with an electron microscope 1200EX (JEOL Ltd).

\section{RT-PCR}

Total RNA was extracted using Trizol reagent (GIBCO) and RT-PCR was performed. At least three replicate experiments were performed for each time point. One $\mu \mathrm{g}$ of total RNA was reverse-transcribed by SuperScript II reverse-transcriptase (Invitrogen Life Technologies) using an oligo(dT) primer. RT reactions were carried out according to the manufacturer's protocol. The resulting RT reaction mixture was diluted five-fold, and $2 \mu \mathrm{l}$ was used as template in RT-PCR reactions. PCR was performed for 35 cycles, with each cycle consisting of $94^{\circ} \mathrm{C}$ for $30 \mathrm{sec}$, $55^{\circ} \mathrm{C}$ for $40 \mathrm{sec}$ and $72^{\circ} \mathrm{C}$ for $1 \mathrm{~min}$, with additional $7 \mathrm{~min}$ incubation after completion of the last cycle. We used the following primers to detect these transcripts:

\section{Nkx2.5 -forward: $\quad$ 5'- TTCTCTCAGGCGCAGGTGTACGAGC -3' Nkx2.5 -reverse: 5'- GCAGGGTAGGCGTTGTA -3'}


amhc -forward: amhc-reverse: mhc1 -forward: mhc1 -reverse: cmlc2 -forward: cmlc2 -reverse: $E F-1 \alpha$-forward: $E F-1 \alpha$-reverse:

\section{5'- ATGATGGCIGAGGAGCTGAAGAA -3' 5'- GGTCATGATGTTCTTGTCGTAGTAG -3' 5'- GGAGCTGGATGATGTGGTTTC -3' 5'- CATGGGCTAAGGCGTTCTTGGC -3' 5'- AATGTCTTTTCCATGTTCGAAC -3' 5'- CTCCTCTTTCTCAATCACCATG -3 5'- ATCGTTGCTGCTGGTGTTG -3' 5'- AGGCGATGTGAGCTGTGTG -3'}

$N k \times 2.5$ is a cardiac specific homeobox gene. Atrium myosin heavy chain (amhc) is expressed specifically in atrium cardiomyocytes, and myosin heavy chain 1 (mhc1) is specific for ventricle cardiomyocytes. Cardiac myosin light chain2 $(\mathrm{cm} / \mathrm{c} 2)$ is expressed in both atrium and ventricle. (Kudo, A. and Kawakami, A., personal communication). Amplification of elongation factor- $1 \alpha(E F-1 \alpha)$ was used in all experiments as a positive control to ensure the quality of the mRNA.

\section{Action potential recording}

Electrophysiological studies were performed in 199 medium containing $1.8 \mathrm{mmol} / \mathrm{L} \mathrm{CaCl}, 5.37 \mathrm{mmol} / \mathrm{L} \mathrm{KCl}$, and $25 \mathrm{mmol} / \mathrm{L} \mathrm{HEPES} \mathrm{(pH} \mathrm{7.4).}$ A Culture dish was placed on a stage of an inverted phase contrast microscope (IX-70, Olympus) at $20^{\circ} \mathrm{C}$. Action potentials were recorded using a conventional glass microelectrode filled with $3 \mathrm{~mol} / \mathrm{L} \mathrm{KCl}$ and having a DC resistance of 15-30 $\mathrm{M} \Omega$. Intracellular recordings were made from 2-week cultured cells. Membrane potentials were measured by means of the current clamp mode (MEZ-8300, Nihon Kohden) with a builtin 4-pole Bessel filter set at $1 \mathrm{kHz}$.

\section{Pharmacological responses}

Phenylephrine (an $\alpha_{1}$ - adrenergic receptor agonist; Sigma p-6126), isoproterenol ( $a \beta_{1}$-adrenergic receptor agonist; Sigma I-2760), clenbuterol (a $\beta_{2}$-adrenergic receptor agonist; Sigma C-5423) and diltiazem (a calcium channel blocker; Sigma D-2521) were used to study pharmacological responses of the spontaneously contracting cells. These reagents were dissolved in dimethyl sulfoxide at high concentrations and $1 \mu \mathrm{l}$ solution was added to each culture medium. Final concentrations were as indicated in Fig. 5.

\section{Purification and characterization of the protein factor}

Solid ammonium sulfate was added to ten liters of $\mathrm{CM}-1$ until $50 \%$ saturation was reached. The mixture was centrifuged at $13,500 \mathrm{Xg}$ for 20 $\mathrm{min}$ and the precipitate was dissolved in a $20 \mathrm{mmol} / \mathrm{L}$ Tris- $\mathrm{HCl}$ buffer $(\mathrm{pH}$ 7.5 , basal buffer). The solution was extensively dialyzed against the basal buffer and then centrifuged as described above. The supernatant was applied to a SP-Sephadex column (5.6X7 cm, Amersham Bioscience Co.) previously equilibrated with the basal buffer. The column was washed with the basal buffer containing $20 \mathrm{mmol} / \mathrm{L} \mathrm{NaCl}$. Proteins with cardiac cell-inducing activity were eluted using the basal buffer containing 100 $\mathrm{mmol} / \mathrm{L} \mathrm{NaCl}$. The active fractions were pooled and solid ammonium sulfate was added to $50 \%$ saturation. Then, the precipitate was collected by centrifugation, dissolved in basal buffer and applied to a Sephadex G75 column (3.6X90 cm, Amersham Bioscience Co.) previously equilibrated with basal buffer containing $0.5 \mathrm{~mol} / \mathrm{L} \mathrm{NaCl}$. The activity was eluted as a single peak at a position corresponding to a molecular weight of 24$28 \mathrm{kDa}$. The collected fractions were concentrated using Vivaspin 20 columns (10,000 MWCO PES, VIVASCIENCE), and applied to a hydroxylapatite column (1.0X1 cm, Bio-Gel http Gel, Bio-Lad Laboratories). The column was washed with a $50 \mathrm{mmol} / \mathrm{L}$ potassium phosphate buffer (KPB, $\mathrm{pH} 7.15$ ) and proteins were eluted with a linear gradient of $50-150 \mathrm{mmol} /$ $\mathrm{L} K P B$ at a flow rate of $0.5 \mathrm{ml} / \mathrm{min}$.

The active fractions from three runs of hydroxylapatite column chromatography were collected and concentrated using Vivaspin columns. The concentrated solutions were dialyzed against basal buffer and then applied to an HPLC SP-Sepharose FF column $(0.5 \mathrm{X} 1 \mathrm{~cm}$, Amersham Bioscience Co.), which had been equilibrated with the same buffer. After the column was washed with $10 \mathrm{ml}$ of the same buffer, proteins adsorbed to the column were eluted with a linear gradient of $0-100 \mathrm{mmol} / \mathrm{L} \mathrm{NaCl}$ in basal buffer at a flow rate of $0.5 \mathrm{ml} / \mathrm{min}$. The proteins from the peak fraction were digested with trypsin and analysed using an Ultraflex TOF/ TOF mass spectrometer (Brukar Daltonics K. K.).

\section{Statistics}

Data are expressed as mean $\pm S E$. Statistical discriminations were performed with Student's t test with $\mathrm{P}<0.05$ considered significant.

\section{Acknowledgments}

We thank Kamiguchi, H., Tsukamoto, H., Hasegawa, H., Kameyama, Y., Itoh, J. and Akatsuka, A., for technical assistance, Ono, M. for cell culture and RT-PCR analysis, Yamada, T., Nirasawa, T., and Kasai, S. for mass spectrometer analysis. We also thank Kubodera, S. and Nishii, Y. for helpful discussions. We are grateful to Kaji, E. H. for critically reading the manuscript. This study was supported by Grants-in-Aid from the Ministry of Education, Culture, Sports, Science and Technology, Japan (13878176 to M.H., 14657035 to M.T.).

\section{References}

ARIIZUMI, T. and ASASHIMA, M. (2001). In vitro induction systems for analyses of amphibian organogenesis and body patterning. Int. J. Dev. Biol. 45: 273-279.

ARIIZUMI, T., KINOSHITA, M., YOKOTA, C., TAKANO, K., FUKUDA, K., MORIYAMA, N., MALACINSKI, G.M. and ASASHIMA, M. (2003). Amphibian in vitro heart induction: a simple and reliable model for the study of vertebrate cardiac development. Int. J. Dev. Biol. 47: 405-410.

ARIIZUMI, T., KOMAZAKI, S., ASASHIMA, M. and MALACINSKI, G. M. (1996). Activin treated urodele ectoderm: a model experimental system for cardiogenesis. Int. J. Dev. Biol. 40: 715-718.

ASASHIMA, M. (1994). Mesoderm induction during early amphibian development. Dev. Growth \& Differ. 36: 343-355.

ASASHIMA, M., ARIIZUMI, T. and MALACINSKI, G.M. (2000). In vitro control of organogenesis and body patterning by activin during early amphibian development. Comp. Biochem. Physiol. B Biochem. Mol. Biol. 126: 169-178.

BARRON, M., GAO, M. and LOUGH, J. (2000). Requirement for BMP and FGF signaling during cardiogenic induction in non-precardiac mesoderm is specific, transient, and cooperative. Dev. Dyn. 218: 383-393.

BRAND, T. (2003). Heart development: molecular insights into cardiac specification and early morphogenesis. Dev. Biol. 258: 1-19.

DENNING, C., ALLEGRUCCI, C., PRIDDLE, H., BARBADILLO-MUNOZ, M. D ANDERSON, D., SELF, T., SMITH, N. M., PARKIN, C. T. and YOUNG, L. E. (2006). Common culture conditions for maintenance and cardiomyocyte differentiation of the human embryonic stem cell lines, BG01 and HUES-7. Int. J. Dev. Biol. 50: 27-37.

FAN, L. and COLLODI, P. (2006). Zebrafish embryonic stem cells. Methods Enzymol. 418: 64-77.

FUKUDA, K. and YUASA, S. (2006). Stem cells as a source of regenerative cardiomyocytes. Circ Res. 98: 1002-1013.

HONG, Y., WINKLER, C. M. and SCHARTL, M. (1998). Efficiency of cell culture derivation from blastula embryos and of chimera formation in the medaka (Oryzias latipes) depends on donor genotype and passage number. Dev. Genes. Evol. 0208: 595-602.

HYODO, M., KATSUMATA, M., TAKAGI, S., TAKADA, T., MIYAJIMA, S., MOROZUMI, T. and MATSUHASHI, M. (1998). Characterization of developmental potential in isolated medaka blastomeres and cultured embryonic cells J. Mar. Biotechnol. 6: 23-29.

IWAMATSU, T. (2004). Stages of normal development in the medaka Oryzias latipes. Mech. Dev. 121: 605-618.

KASAHARA, M., NARUSE, K., SASAKI, S., NAKATANI, Y., QU, W., AHSAN, B., YAMADA, T., NAGAYASU, Y., DOI, K., KASAI, Y., JINDO, T., KOBAYASHI, D., SHIMADA, A., TOYODA, A., KUROKI, Y., FUJIYAMA, A., SASAKI, T., SHIMIZU, A., ASAKAWA, S., SHIMIZU, N., HASHIMOTO, S., YANG, J., LEE, Y., MATSUSHIMA, K., SUGANO, S., SAKAIZUMI, M., NARITA, T., OHISHI, K., 
HAGA, S., OHTA, F., NOMOTO, H., NOGATA, K., MORISHITA, T., ENDO, T., SHIN-I, T., TAKEDA, H., MORISHITA, S. and KOHARA, Y. (2007). The medaka draft genome and insights into vertebrate genome evolution. Nature 447: 714719.

KEHAT, I., KENYAGIN-KARSENTI, D., SNIR, M., SEGEV, H., AMIT, M., GEPSTEIN, A., LIVNE, E., BINAH, O., ITSKOVITZ-ELDOR, J. and GEPSTEIN, L. (2001). Human embryonic stem cells can differentiate into myocytes with structural and functional properties of cardiomyocytes. J. Clin. Invest. 108: 407-414.

LADD, A.N., YATSKIEVYCH, T.A. and ANTIN, P.B. (1998). Regulation of avian cardiac myogenesis by activin/Tgf $\beta$ and bone morphogenetic proteins. Dev. Biol. 204: 407-419.

LAFLAMME, M.A., CHEN, K.Y., NAUMOVA, A.V., MUSKHELI, V., FUGATE, J.A., DUPRAS, S.K., REINECKE, H., XU, C., HASSANIPOUR, M., POLICE, S., O'SULLIVAN, C., COLLINS, L., CHEN, Y., MINAMI, E., GILL, E.A., UENO, S.,YUAN, C., GOLD, J. and MURRY, C.E. (2007). Cardiomyocytes derived from human embryonic stem cells in pro-survival factors enhance function of infarcted rat hearts. Nature Biotechnol. 25: 1015-1024.

LOUGH, J., BARRON, M., BROGLEY, M., SUGI, Y., BOLENDER, D.L. and ZHU, X. (1996). Combined BMP-2 and FGF-4, but neither factor alone, induces cardiogenesis in non-precardiac embryonic mesoderm. Dev. Biol. 178: 198202.

LOUGH, J. and SUGI, Y. (2000). Endoderm and Heart Development. Dev. Dyn. 217: 327-342.

PASSIER, R., OOSTWAARD, D.W., SNAPPER, J., KLOOTS, J., HASSINK, R.J., KUIJK, E., ROELEN, B., DE LA RIVIERE, A.B. and MUMMERY, C. (2005). Increased cardiomyocyte differentiation from human embryonic stem cells in serum-free cultures. Stem Cells 23: 772-780.

SCHULTHEISS, T.M., XYDAS, S. and LASSAR, A.B. (1995). Induction of avian cardiac myogenesis by anterior endoderm. Development 121: 4203-4214.

SEDOHARA, A., SUZAWA, K. and ASASHIMA, M. (2006). Comparison of induction during development between Xenopus tropicalis and Xenopus laevis. Int. J. Dev. Biol. 50: 385-392.

SUGI, Y. and LOUGH, J. (1995). Activin-A and FGF-2 mimic the inductive effects of anterior endoderm on terminal cardiac myogenesis in vitro. Dev. Biol. 168: 567-574.

TADA, T., HIRONO, I., AOKI, T. and TAKASHIMA, F. (1998). Cloning and sequencing of carp and medaka activin subunit genes. Fish Sci. 64: 680-685.

TAKAHASHI, K., TANABE, K., OHNUKI, M., NARITA, M., ICHISAKA, T., TOMODA, K. and YAMANAKA, S. (2007). Induction of pluripotent stem cells from adult human fibroblasts by defined factors. Cell 131: 861-872.

TAKAHASHI, K. and YAMANAKA, S. (2006). Induction of pluripotent stem cells from mouse embryonic and adult fibroblast cultures by defined factors. Cell 126: 663-676.

THOMSON, J.A., ITSKOVITZ-ELDOR, J., SHAPIRO, S.S., WAKNITZ, M.A., SWIERGIEL, J.J., MARSHALL, V.S. and JONES, J.M. (1998). Embryonic stem cell lines derived from human blastocysts. Science 282: 1145-1147.

VAN LAAKEA, L.W., PASSIER, R., MONSHOUWER-KLOOTS, J., VERKLEIJ, A.J., LIPS, D.J., FREUND, C., DEN OUDEN, K., WARD-VAN OOSTWAARD, D., KORVING, J., TERTOOLEN, L.G., VAN ECHTELD, C.J., DOEVENDANS, P.A. and MUMMERY, C.L.(2007). Human embryonic stem cell-derived cardiomyocytes survive and mature in the mouse heart and transiently improve function after myocardial infarction. Stem Cell Res. 1: 9-24.

WITTBRODT, J. and ROSA, F.M. (1994). Disruption of mesoderm and axis formation in fish by ectopic expression of activin variants: the role of maternal activin. Genes \& Dev. 8: 1448-1462.

XU, C., POLICE, S., RAO, N., and CARPENTER, M,K. (2002). Characterization and enrichment of cardiomyocytes derived from human embryonic stem cells. Circ. Res. 91: 501-508.

YATSKIEVYCH, T.A., LADD, A.N. and ANTIN, P.B. (1997). Induction of cardiac myogenesis in avian pregastrula epiblast: the role of the hypoblast and activin. Development 124: 2561-2570.

YUTZEY, K.E. and KIRBY, M.L. (2002). Wherefore heart thou? Embryonic origins of cardiogenic mesoderm. Dev. Dyn. 223: 307-320.

ZAFFRAN, S. and FRASCH, M. (2002). Early signals in cardiac development. Circ. Res. 91: 457-469. 


\section{Further Related Reading, published previously in the Int. J. Dev. Biol.}

See our recent Special Issue Fertilization, in honor of David L. Garbers and edited by Paul M. Wassarman and Victor D. Vacquier at: http://www.ijdb.ehu.es/web/contents.php?vol=52\&issue=5-6

The heart forming region of early chick embryo is an alternative source of embryonic stem cells Seema Borgave, Kirti Ghodke and Surendra Ghaskadbi

Int. J. Dev. Biol. (2009) 53: 91-99

The enigmatic role of the ankyrin repeat domain 1 gene in heart development and disease Alexander T. Mikhailov and Mario Torrado

Int. J. Dev. Biol. (2008) 52: 811-821

Xenopus glucose transporter 1 (xGLUT1) is required for gastrulation movement in Xenopus laevis

Keiko Suzawa, Akira Yukita, Tadayoshi Hayata, Toshiyasu Goto, Hiroki Danno, Tatsuo Michiue, Ken W. Cho and Makoto Asashima

Int. J. Dev. Biol. (2007) 51: 183-190

Common culture conditions for maintenance and cardiomyocyte differentiation of the human embryonic stem cell lines, BG01 and HUES-7

Chris Denning, Cinzia Allegrucci, Helen Priddle, Maria D. Barbadillo-Muñoz, David Anderson, Tim Self, Nigel M. Smith, C. Tony Parkin and Lorraine E. Young Int. J. Dev. Biol. (2006) 50: 27-37

Loss of beta1 integrin function results in upregulation of connexin expression in embryonic stem cell-derived cardiomyocytes

Jaroslaw Czyz, Kaomei Guan2, Qinghua Zeng3 and Anna M. Wobus

Int. J. Dev. Biol. (2005) 49: 33-41

A P19CI6 GFP reporter line to quantify cardiomyocyte differentiation of stem cells. Jennifer C Moore, Rene Spijker, Anton C Martens, Teun de Boer, Martin B Rook, Marcel A G van der Heyden, Leon G Tertoolen and Christine L Mummery

Int. J. Dev. Biol. (2004) 48: 47-55

2006 ISI ${ }^{* *}$ Impact Factor $=3.577^{* *}$

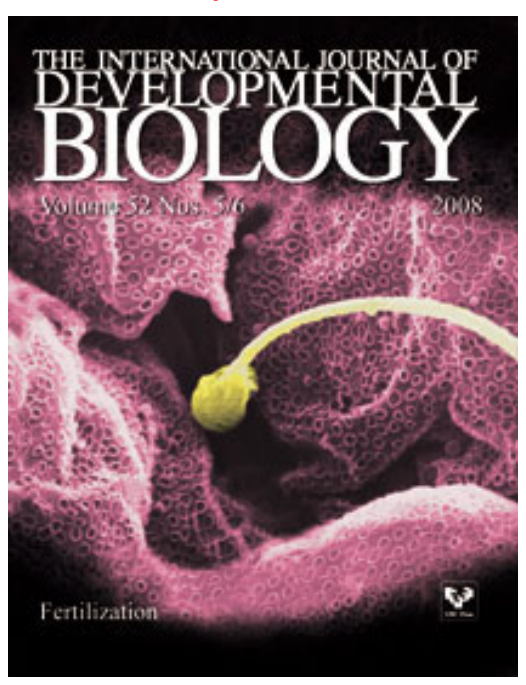

